\title{
ACRL preconferences in Nashville
}

Gain practical new skills you can apply in your library

A CRL is offering the following preconferences prior to its 8th National Conference in Nashville, April 11-14, 1997. Select one or more of these seminars and gain practical new tools that can benefit your library. Update your knowledge with topics such as digitizing collections, fundraising, preferred futures, the learning organization, using digital information, designing the library building of the furure, technical services workstations, new learning communities, and providing data services. Check future issues of CERL News for additional preconferences. Unless otherwise noted, preconferences will be held in the Convention Center or a conference hotel.

\section{Friday, April 11 \\ Preferred Library Futures}

It is possible for you and your staff to create the futures you prefer for your organization. One need not be a captive to the futures the experts predict. Why do we presume they are prescient? You can take control, envision where you want your library to be, and develop strategies to get there. Attend this preconference and gain practical tools you can use back home to move your organization toward its preferred future. The process is both creative in nature and practical in outcome. Attendees will refurn home with problem-solving processes they can use in a variety of situations. Attendees will also gain insight about organizational change. For example, what are the conditions that must be present before an organization is likely to change? Presenter: Richard Dougherty, an academic librarian who is currently a professor in the School of Information at the University of Michigan and associated with the Lippitt Planned Change Institute. Dougherty has worked with many groups of librarians, pro- vosts, computing professionals, publishers, etc. He also works with individual libraries in the public and academic sectors. He has conducted preferred futuring workshops in Ireland, England, Denmark, South Africa, and Israel.

$\$ 150$ ACRL members; $\$ 180$ ALA members; $\$ 220$ nonmembers

\section{Friday, April 11}

1:00-4:30 p.m.

Georeferenced Information in a Digital World: Putting your Library on the Map Learn how to effectively and efficiently use vital demographic, geographic, and environmental information available in a digital form, and how to find out about maps, aerial photographs, and satellite images over the World Wide Web. This hands-on workshop (each participant will work at a computer with an Internet connection) will examine the Alexandria Digital Library (one of six NSF/ARPA/NASA Digital Library Initiatives) that focuses on online access to spatial data and other georeferenced information. You will learn how to find spatial data in digital form on the Web; and how to identify software, hardware, and staff requirements for dealing with online access to spatial data. Presenters: Josepb Boissé, university librarian, University of California, Santa Barbara; Terence Smith, executive director, Alexandria Digital Library; Randall Kemp, digital-data librarian, Alexandria Digital Library; Mary Lynette Larsgaard, assistant bead, Map and Imagery Lah, University of California, Santa Barbara. Location: Vanderbilt Iniversity. Enrollment limited to first 31 registrants.

$\$ 65$ ACRL members; \$75 ALA members; \$85 nonmembers

\section{Friday, April 11}

\section{Building the New Age Library}

If you are charged with building or renovating a library building, you need to consider how some of the changes experienced by higher education - such as the increasing use of technology, collaborative learning styles, the in- 
crease in interdisciplinary studies, the expansion of delivery to distance learners, and the evolution of the lifelong learner-play out on your campus and how the library building can contribute to the evolution of the university into 21 st-century institutions. This involves a great deal more than putting technology in libraries, and it challenges some of our basic assumptions about the library as a place of quiet study and contemplation, and as a depository of the world's wisdom. This preconference will examine new ways of thinking about library buildings, provide practical examples of how to plan the library building of the future, and share concrete information about what has worked and what hasn't. George Mason University's Johnson Center Library - a library sharing space in a building with food services, bookstore, computer labs, movie theater, and an innovative undergraduate program-will be the central case study of the program. Designers of the building will trace its evolution from the initial concept through the first year of occupancy and discuss the influence of the various factors having an impact on higher education and libraries. Presenters: Charlene S. Hurt, director of libraries, George Mason University; Pbilip Tompkins, director of libraries, Indiana University/Purdue University at Indianapolis; and Geoffrey Freeman and Wendall Wickerbam of Shepley Bulfinch Richardson and Abbott.

\$75 ACRL members; \$85 ALA members; \$95 nonmembers

\section{Friday, April 11 \\ 8:30 a.m. $-4: 30$ p.m. Funding Our Future: Fundraising Strat- egies for Libraries}

Learn how you can raise the funds your library needs to achieve its preferred future. This preconference will start with the basics of organizing a new library development program, annual funds, major gifts, and campaigns, and continue through advanced topics such as unique ways of acknowledging library clonors. Participants will gain insight into the mechanics and the art-and-science of fundraising for libraries, strategies for implementing and strengthening already existing fundraising programs, and sharing ideas for new ways to raise money. Ways to fine-tune traditional methods of raising money and acknowledging library contributions will also be covered. Presenters: Four seasoned fundraisers who chose the world of libraries: Adam Corson-Finnerty, director of development, University of Pennsylvania;
Gwendolyn Leighty, development officer, Smithsonian Institution Libraries; Micbele Fletcher, di rector of development, University of Nortb Carolina, Chapel Hill; and Lynn Trojahn, director of development, University of New Mexico.

\$135 ACRL members; \$160 ALA members; \$190 nonmembers

\section{Friday, April 11 9:00 a.m. 4:00 p.m. The Learning Organization: Developing Skills to Work in Teams and Solve Prob- lems}

This workshop will explore the three disciplines of the learning organization which focus more directly on the individual's role and contribution: mental models, personal mastery, and team learning. Participants will learn how to question assumptions, how to engage in meaningful dialogue to develop a better understanding of problems and to solve them, and how to improve both interpersonal and team communication. Although the context is the learning organization model, the workshop will be useful to anyone interested in improving his or her understanding of and skills in interpersonal interaction and communication. Speakers: Shelley E. Phipps, assistant dean for team facilitation, University of Arizona, and Maureen Sullivan, organizational devlopment consultant, Association of Research Libraries (ARL). Both speakers have experience in helping libraries explore how to become learning organizations. \$125 ACRL/ARL members; \$150 ALA members; and $\$ 175$ nonmembers. (Offered by ARL; use separate registration form.)

\section{Friday, April 11} 8:00 a.m. $-4: 00$ p.m.

Seizing the High Ground: (Re)Creating Technical Services with Smart Machines and Networked Librarians

The Technical Services Workstation, suitably outfitted with electronic tools and in conjunction with the Internet and Z39.50, promises to revolutionize the future of technical services operations into a tightly integrated processing environment. This revolution will not happen without planning and training and a thorough understanding of the evolving technology and its implications for human and machine resources. The experts assembled for this preconference-a potent mix of theorists, developers, and practitioners-will address these issues within an overall perspective and place them squarely within the context of the challenges facing academic libraries. Learn how to 
address staff training issues, see examples of productivity enhancements developed in real settings, and gain a vision of the future of technical services. (Note: this preconference, sponsored by the Association for Library Collections and Technical Services (ALCTS), has been completely updated from previous presentations in the ALCTS TSW institute series.) Speakers: Howard Harris, vice-president, RMG Consultants; Bruce Jobnson, senior library information systems analyst, Library of Congress; Michael Kaplan, bead, database management and coordinator for OCLC/RLIN operations, Harvard College; David Williamson, senior descriptive cataloger, Library of Congress; and Diane Vizine-Goetz, consulting research scientist, OCLC. \$145 ACRL/ALCTS members; \$195 ALA members; and $\$ 245$ nonmembers

\section{Friday, April $11 \quad 8: 30$ a.m.12:00 p.m. User Needs: Service Models for Data Libraries}

Collections of machine-readable numeric data pose a new challenge for the library. Many academic libraries have begun developing digital collections (images and electronic text). These collections may require individualized assistance from the data library staff forcing us to develop a new model of service. Using the Social Sciences Data Center at the University of Virginia as a backdrop, this preconference will explore service issues associated with data libraries, and will give participants the opportunity to discuss similar projects and initiatives in their own institutions. You will learn about financial and staffing issues, how to determine user needs for data and service, and examine service models. You will also be able to identify technological and programming requirements as well as opportunities for innovation and partnership. Speaker: Patrick Yott, coordinator of social sciences data services, University of Virginia. \$65 ACRL members; \$75 ALA members; \$85 nonmembers

\section{Friday, April 11 Digitizing Archival Collections}

Learn how to digitize your archival collections for online distribution. The Ava Helen and Linus Pauling Papers and the Thomas A. Edison Papers - two documentary projects digitizing their collections for online access - will be used to discuss and demonstrate their approaches to putting digitally processed archival materials online. The Pauling Papers, an archival collection at Oregon State University, is establishing an electronic archive that includes typed and handwritten material, using proprietary software to organize the archive and optical characters recognition to index the large number of typewritten documents in the collection. The Edison Papers, a documentary publishing project that has published a selective edition of the full Edison archive in microfilm and a more selective edition of transcriptions in printed volumes, is scanning its film to create images of the documents. The Edison project will eventually provide SGML-tagged text, including editorial material now in its published volumes as well as document transcriptions linked to document images. Speakers: Robert Rosenberg, director, Thomas A, Edison Papers, Rutgers University; Chff Mead, special collections librarian, and Ramesh S. Krishnamurtby, project director, Ava Helen and Linus Pauling Papers, Oregon State University. \$65 ACRL members; \$75 ALA members; \$85 nonmembers

\section{Friday, April $11 \quad 8: 30$ a.m. $-4: 30$ p.m. New Learning Communities: Collabo- ration through Technology}

This preconference will focus on the process of forming successful New Learning Communities through partnerships of faculty, librarians, information technologists, and others. Presentations by team members and educational leaders will help participants gain an understanding of the concepts involved in successful collaborations; exposed them to examples of New Learning Communities in which student involvement and the teaching/learning process are emphasized; and see projects from model programs. The University of Washington's UWired project will be used as a case study to illustrate one approach to bringing technology into the service of teaching and learning. Characteristics of the new learning community, how to create a learning environment, and assessment and evaluation will be covered. Speakers: Philip Tompkins, Indiana University/Purdue University at Indianapolis (IUPUD); Randy Hensley, University of Hawait; Mary McMabon, Gettysburg College; Susan Perry, Mt. Holyoke College; Betsy Wilson, Andi Bartelstein, Bunny Laden, and Anne Zald, University of Washington; Karen Williams, University of Arizona; Peggy Seiden, Skidmore College; and Mary Jane Petrowski, Colgate University.

\$150 ACRL members; \$180 ALA members; \$220 nonmembers 


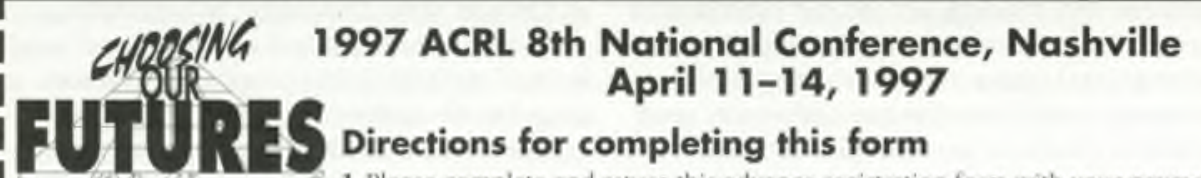

1. Please complete and return this advance registration form with your payment of charge cand information. Fax of mail to:

ACRL Eighth National Conference Registration
50 East Huron Street
Chicago, II. $60611-2795$
Pax: (312) 280-2520; phone: (312) 280-2519

2. Save money by registering at the Early Bird rate. Return your form by January 8, 1997.

3. Final deadline for advance registration forms is March 7, 1997. Forms received after that date will be subject to a $\$ 45$ late fee.

4. Refund requests must be submitted in writing prior to March 5, 1997, and are subject to a $\$ 50$ cancellation fee. Refunds will be processed and mailed after May 15, 1997.

\section{Confirmation}

Your badge and receipt will be sent to this address. If we receive your registration by March 7,1997 .

Name

-

Address

1

City State Zip

Daytime Phone

Fax

F-mail

MLA, ALA, or state chapter member no.

\section{Badge Information}

Please print exactly what you want to have printed on your badge.

First name

Last name

1

Organization name

Organization city State

$\square$ I will require Americans with
Disabilities Ad special assistance on
site. An ACRI stafJ member will
contact you.

All preconferencos are offerwi on a cost-reotery basis and may be cancelled if tbere is insulficient registration. In the etent that an ACRL-sponsored actieity is cancelled. ACRL cannot be noponsible for any cancellation ichange charyes aswered to registrants by airlines, mavel apencies, or botels

\section{Registration Fees (Circle one)}

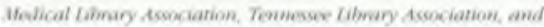
Kentucly Libnan Acociation nembers in may noxister at the ACKI member nut

\begin{tabular}{|c|c|c|c|}
\hline & $\begin{array}{l}\text { Until } \\
\text { Jan. } 8\end{array}$ & $\begin{array}{l}\text { Jan. 9- } \\
\text { Mar. } 7\end{array}$ & Onsite \\
\hline CRI personal memb. & $\$ 225$ & $\$ 270$ & $\$ 315$ \\
\hline LA personal memb. & 5275 & $\$ 330$ & $\$ 375$ \\
\hline onmember & $\$ 350$ & $\$ 120$ & $\$ 465$ \\
\hline $\begin{array}{l}\text { Pull-time library } \\
\text { school student }\end{array}$ & 595 & $\$ 114$ & $\$ 159$ \\
\hline
\end{tabular}

\section{Preconferences}

Preferred Library Futures Georeferenced Information

ACRI AIA Nonmemb. memb. memb. $\$ 150 \quad \$ 180 \quad \$ 220$

$\$ 65 \quad \$ 75 \quad \$ 85$ Building the New Library $\quad \$ 75 \quad \$ 85 \quad \$ 95$ Funding Our Futures $\quad \$ 135 \quad \$ 160 \quad \$ 190$ Seizing the High Ground $\quad \$ 145 \quad \$ 195 \quad \$ 245$ User Needs $\quad \$ 65 \quad \$ 75 \quad \$ 85$ $\begin{array}{llll}\text { Digitizing Archival } \$ 665 & \$ 75 & \$ 85\end{array}$ New Learning Communities $\$ \$ 150 \quad \$ 180 \quad \$ 220$ The Learning Organization (use separate form)

\section{Summary of fees}

I. Registration $\$$

II. Preconferences $\$$

Total $\$$

\section{Method of payment}

Check enclosed (payable to ACRL) Charge

$\square$ VISA $\square$ MasterCard $\square$ AmEx

Expiration Date

Signature 


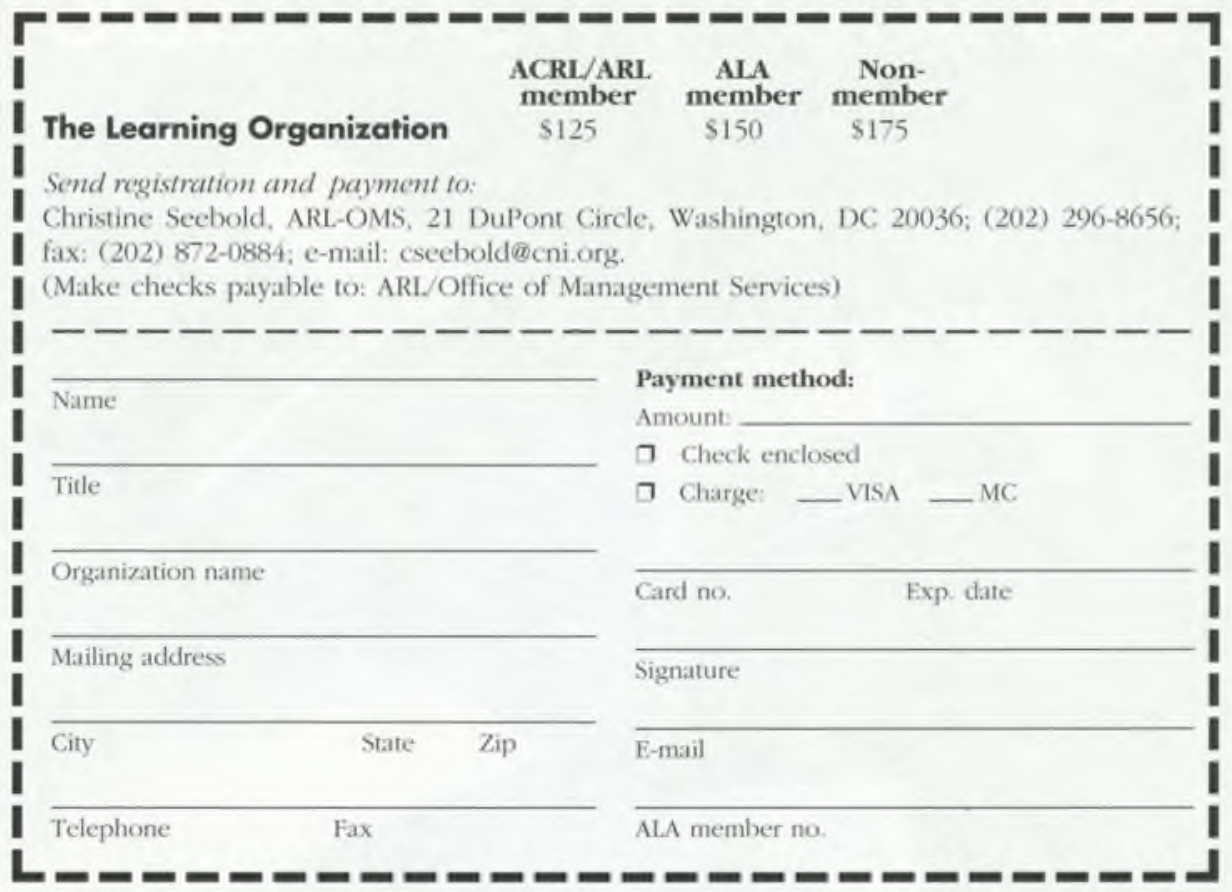

(Intemet cont. from page 660)

lection of feature films with gay, lesbian, transgender, or bisexual themes. Access: www.planetout.com/kiosk/popcornq

\section{Journalism}

- Queer Press International. A comprehensive site providing access to all aspects of gay and leshian journalism from weekly summaries and organizational news to Rex Wockner's international monitoring of gay and lesbian events worldwide. A particularly useful feature is the list of those publications that have Web addresses. Access: http://cyberzine.org/ html/GLAIDS/QPI/ qPipage.html.

- The ADVOCATE. Referred to as "the New York Times of gay America," this comprehensive magazine has been published since september 1967. Access: http://www.advocate.com.

- Harvard Gay and Lesbian Review. One of the leading new journals in the field of gay and lesbian studies. Access: http:// www.hglc.org/hglc/review.htm.

- Seattle Gay News Online. One of the major news sources for the Pacific Northwest's gay community. Access: http://www.sgn.org/sgn.

- Out in the Mountains. Vermont's newspaper for lesbian, gay, bisexual, and transgender issues. Access: http://members.aol.com/oitm/ oitm.htm.

\section{Politics}

- Gay and Lesbian Politics: WWW and Internet Resources. This list is intended as a comprehensive resource on the roles, participation, attitudes, and behaviors of, and issues of concern to, gay men and lesbians in American politics. Access: http://ezinfo.ucs. indiana.edu/ sanderss/gaylespolguide.html.

- Queer Planet. An international list for gay, leshian, and bisexual persons who want to work as community organizers. Access: majordomo@vector.casti.com. Subscribe. "queerplanet."

\section{Domestic partnership}

- Domestic Partnerships and Same Sex Marriages. The best site for beginning research into this controversial issue. Areas covered include the precise legal definition of family, sample domestic partner policies (and a list of those companies and institutions that have them), and the same-sex marriage case currently being heard in Hawaii. Access: http:// www.cs.cmu.edu/afs/cs/cmu.edu/user/scotts/ domestic-partners/mainpage.html. 


\section{Set your information fre}

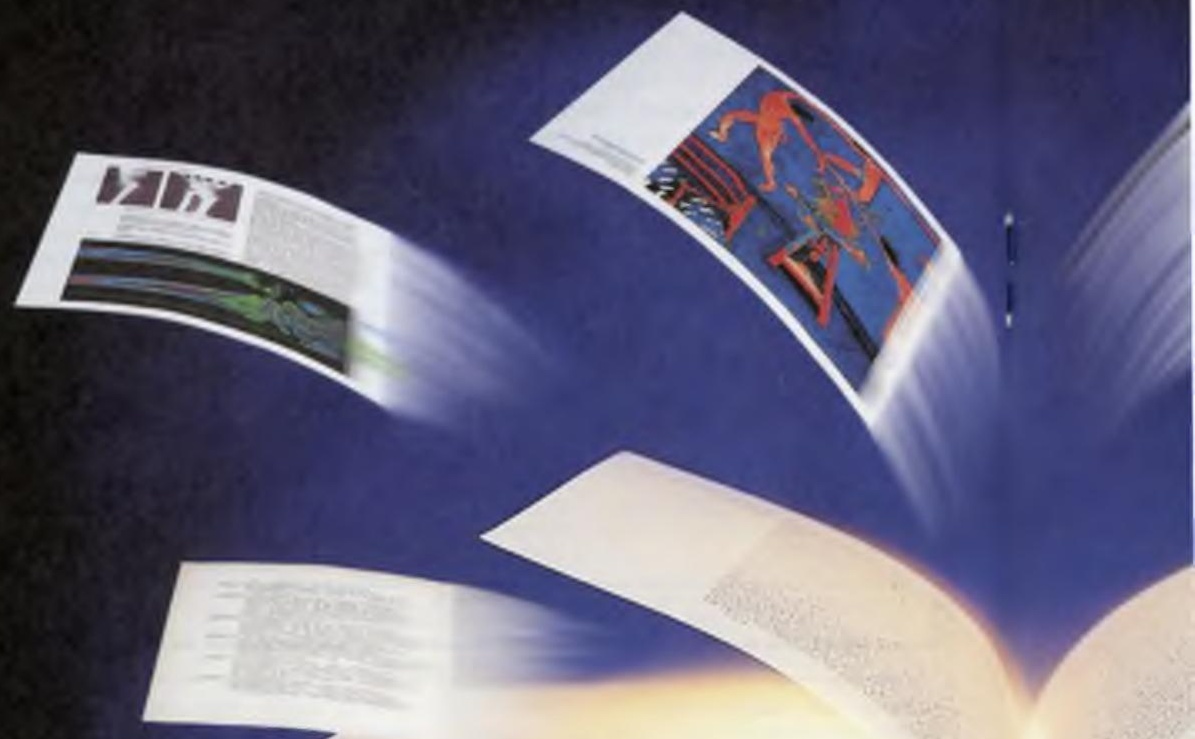

Scan any bound document tace up and damage-tree in seconds.

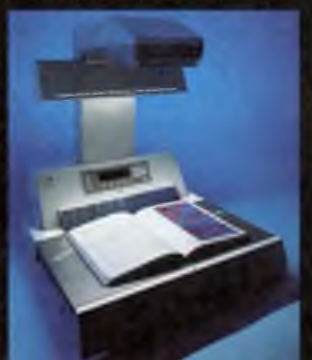

\section{Introducing Minolta}

Scan, copy and send information from any bound document interoffice, interlibrary or internationally. Bound up by bound documents? Digitize and distribute information worldwide with one of the EPIC 3000 systems. Scan fragile books, documents and even 3-D objects face up and damage-free. Then archive or distribute the information however you please. EPIC 3000 for Windows ${ }^{\text {Ty }}$ lets you prin Store on an The patroncomes read Don't get ca

For more in 


\section{in freel

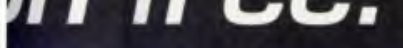

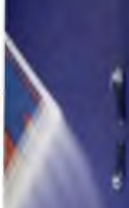

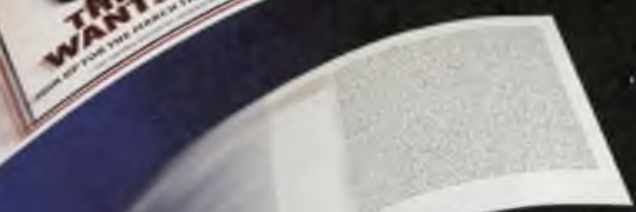

Only from the mind

of Minolia

Copiers

Cameras

Faxes

Digital Systems

Document Imaging

Cameorders

Binoculars

Color Sensors

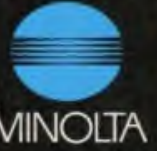

\section{olta EPIC 3000}

ound

onally.

ibute

systems.

acts

oute the

indows ${ }^{\text {Th }}$ lets you print or fax. E-mail information.

Store on any form of media. Or put it on the Internet. The patron-friendly EPIC 3000 with touch screen comes ready for paper or electronic output.

Don't get caught in a bound document bind.

For more information call 1-800-9-MINOLTA
Simple touch screen monitor lets patrons print or store to disk.

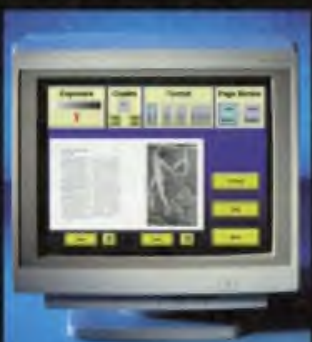

